Article

\title{
A Feasibility Assessment of Photovoltaic Power Systems in Ireland; a Case Study for the Dublin Region
}

\author{
Fionnuala Murphy ${ }^{1,3, *}$ and Kevin McDonnell ${ }^{2,3}$ \\ 1 School of Biosystems \& Food Engineering, University College Dublin, Agriculture Building, \\ UCD Belfield, Dublin 4, D04 V1W8, Ireland \\ 2 School of Agriculture and Food Science, University College Dublin, Agriculture Building, \\ UCD Belfield, Dublin 4, D04 V1W8, Ireland; kevin.mcdonnell@ucd.ie \\ 3 Biosystems Engineering Ltd., NovaUCD, Belfield innovation Park, University College Dublin, \\ Dublin 4, D04 V1W8, Ireland \\ * Correspondence: fionnuala.murphy@ucd.ie; Tel.: +35-317-167-317
}

Academic Editors: Jiawei Gong, Qiquan Qiao, Zhengping Zhou, Tingting Xu, Mao Liang and Wenfeng Zhang Received: 18 November 2016; Accepted: 15 February 2017; Published: 18 February 2017

\begin{abstract}
Photovoltaic (PV) power generation is one of the cleanest sources for producing renewable energy; however uptake on the Irish renewable energy market to date has been low. There is a lack of support for solar PV systems in Ireland; there is currently no solar PV energy feed-in-tariff as there are for other renewable energy systems in Ireland. Despite the current lack of support, the Government has indicated that support for the uptake of solar PV installations will be provided through the provision of a feed-in tariff in the future. The aim of this study was to determine the feasibility of installing PV systems under Irish climatic conditions at a location based in Dublin, Ireland, from a technical, environmental and economic point of view. This was achieved by carrying out a life cycle assessment of potential environmental impacts, and analysis of energy and economic payback times relating to the proposed PV system. Four possible renewable feed-in-tariffs (based on existing feed-in-tariffs for other renewable energy systems) were considered to determine the effect of such tariffs on the overall economics of the proposed PV system. Results show that life cycle GHG emissions are $69 \mathrm{~g} \mathrm{CO}_{2}$-eq per $\mathrm{kWh}$ generated by the system, significantly lower than the current electricity grid mix emissions of $469 \mathrm{~g} \mathrm{CO}_{2}$-eq per $\mathrm{kWh}$. It will take 5.23 years of operation of the solar plant to generate the same amount of energy (in terms of primary energy equivalent) that was used to produce the system itself. The economic payback time varies from 19.3 and 34.4 years depending on the rate of renewable energy feed-in-tariff applied. The costs for the production of PV electricity in this study are higher than is usual in countries where the solar PV market is more developed, e.g., Germany, due to constraints with building integration and lack of experienced PV installers. As more PV is deployed, the Irish PV installer base will increase and 'learning by doing' effects will allow installers to install projects more efficiently and quickly under Irish conditions, leading to significantly reduced costs.
\end{abstract}

Keywords: solar PV; Ireland; greenhouse gas emissions; economic payback time; energy payback time; feasibility

\section{Introduction}

Ireland has minimal indigenous fossil energy resources and as an island is heavily dependent on fossil fuel imports. In addition, fossil fuels (oil, natural gas, coal and peat) accounted for $91.4 \%$ of the total primary energy requirement for electricity in 2014, and heat generation is dominated by fossil fuels; 
natural gas, oil, coal and peat [1]. The combustion of such fossil fuels in energy generation is a major contributor to greenhouse gas emissions (GHG) in Ireland, accounting for $63.3 \%$ (37.06 $\mathrm{Mt} \mathrm{CO}_{2}$-eq) of total national greenhouse gas emissions in 2012 [2]. Ireland is committed, under the European Union (EU) Renewable Energy Directive (RED) 2009/28/EC, to reduce greenhouse gas emissions and to develop alternative energy sources to reduce dependence on finite fossil fuel resources [3]. Under this Directive, Ireland's specific mandatory renewable energy target is $16 \%$, driving the need to develop indigenous renewable energy resources. The National Renewable Energy Action Plan (NREAP) set a target of $40 \%$ electricity consumption target from renewables by 2020 [4], with latest data showing a rate of $22.7 \%$ ( $5479 \mathrm{GWh}$ ) was achieved in 2014 [1]. The majority of renewable energy in Ireland is generated by wind, accounting for $71 \%$ of the renewable electricity contribution, with hydro energy accounted for $11 \%$, and biomass accounting for $8 \%$ in 2014 [1]. The majority of the electricity from biomass is generated by co-firing with peat, to offset peat combustion. Peat combustion produces large volumes of $\mathrm{CO}_{2}$ directly but also indirectly reduces the carbon budget of indigenous peatlands [5]. The uptake of solar power generation in the Irish renewable energy market to date has been low, accounting for less than $0.3 \%$ of total electricity generated in 2012 [6]. Ireland is currently on track to meet the national renewable electricity target of $40 \%$, but is currently behind schedule in meeting the renewable heat target [7]. This has implications for meeting the binding $16 \%$ renewable energy target; the Sustainable Energy Authority of Ireland (SEAI) has estimated that the cost to Ireland may be in the range of $€ 100$ million to $€ 150$ million for each percentage point Ireland falls short of the overall 16\% renewable energy target (Dáil Éireann Debates (Unrevised), Written Answer No. 597 `Renewable Energy Generation Targets' (1 December 2015)).

This study determined the feasibility of installing photovoltaic (PV) systems under Irish climatic conditions at a location based in Dublin, Ireland from a technical, environmental and economic point of view. Specific objectives were to:

- Review the planning requirements regarding the installation of restrictions on the size of PV systems in Ireland,

- Evaluate potential energy generation by PV in Dublin and determine the technical feasible size of installation relative to existing roof space,

- Evaluate the energy and economic payback times relating to the proposed solar PV installation at different renewable energy feed-in tariffs,

- Evaluate the potential environmental impacts of the proposed solar PV installation.

\subsection{Current Status of Solar Energy Systems in Ireland}

There are few grid connected photovoltaic (PV) installations in Ireland. While there exists some standalone commercial and domestic installations, statistics are not available for the installed capacity. There were 49 micro-generation grid connected PV installations connected at the end of 2012, with a total installed capacity of $151 \mathrm{~kW}$ [6]. This figure currently stands at $181 \mathrm{kWp}(\mathrm{kW}$ peak) (78 systems). Small capacity solar PV systems are preferred by householders, with $81 \%$ of solar systems to-date having a capacity of less than or equal to $3 \mathrm{kWp}$ [8].

\subsubsection{Solar PV Potential in Ireland}

Ireland receives between 1100 and $1600 \mathrm{~h}$ of sunshine each year [9]. Sunshine levels are highest in the summer months, May and June, when sunshine duration averages between 5 and $6.5 \mathrm{~h}$ per day over most of the country. December is the dullest month, with average daily sunshine levels ranging from approximately $1 \mathrm{~h}$ in the north to nearly $2 \mathrm{~h}$ in the extreme southeast. Sunshine hours vary through the length of the country, with the extreme south-east receiving most sunshine, averaging over $7 \mathrm{~h}$ a day in early summer. On average, most areas in Ireland get an average of between 3.25 and $3.75 \mathrm{~h}$ of sunshine each day over the course of the year. Ireland is completely covered by cloud for well over $50 \%$ of the time; as such this affects the level of energy arriving at the surface compared to 
the energy arriving at the top of the atmosphere. It requires an unusually fine, sunny day with good visibility to get $75 \%$ of this incoming daily total to be received at the earth's surface. On days with no sun, the surface receives on average $20 \%$ to $25 \%$ of the energy arriving at the top of the atmosphere. The percentage of the energy arriving at the top of the atmosphere, which reaches the surface, has a mean value of $40 \%$ to $47 \%$ during the months March to September and 30\% to $37 \%$ during the months October to February [9].

Figure 1 shows the global irradiation, photovoltaic solar electricity potential in Europe per year. Southern European countries receive the highest levels of solar radiation, while Ireland is at the lower end receiving $900-1300 \mathrm{kWh} / \mathrm{m}^{2}$. This can be compared to two locations in Europe where two of the largest PV installations in the world are currently operating; Moura, Portugal which receives $5830 \mathrm{kWh} / \mathrm{m}^{2}$, and Leipzig, Germany which receives $3440 \mathrm{kWh} / \mathrm{m}^{2}$ [10]. Since 2008, a $46 \mathrm{MW}$ photovoltaic solar plant, covering 250 hectares has been operational near Moura. The cells are silicon microcrystalline technology and the modules are equipped with solar trackers which follow the sun across the sky to optimise energy capture [11]. The 52 MW PV plant, covering 220 hectares, near Leipzig is equipped with cadmium telluride (CdTe) thin film modules [12]. Ireland receives $15 \%-22 \%$ of the global irradiation of Moura, and $26 \%-38 \%$ of the global irradiation of Leipzig.

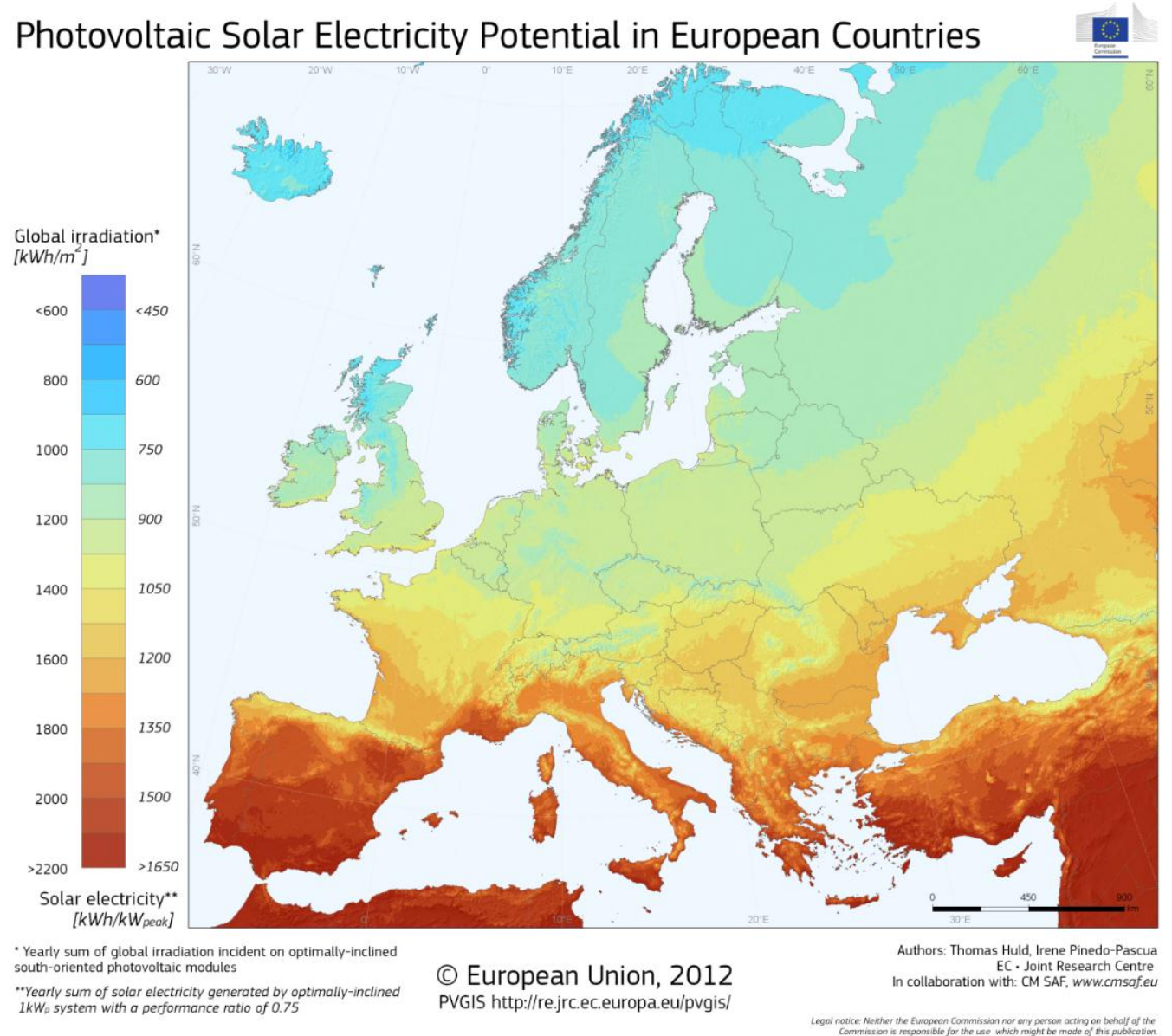

Figure 1. EU Photovoltaic Solar Electricity Potential [13].

Figure 2 shows the solar electricity potential for Ireland, for optimally inclined modules. It can be seen that the east coast south of Dublin has the potential to produce approximately 900 to $1050 \mathrm{kWh} / \mathrm{m}^{2} /$ year. 


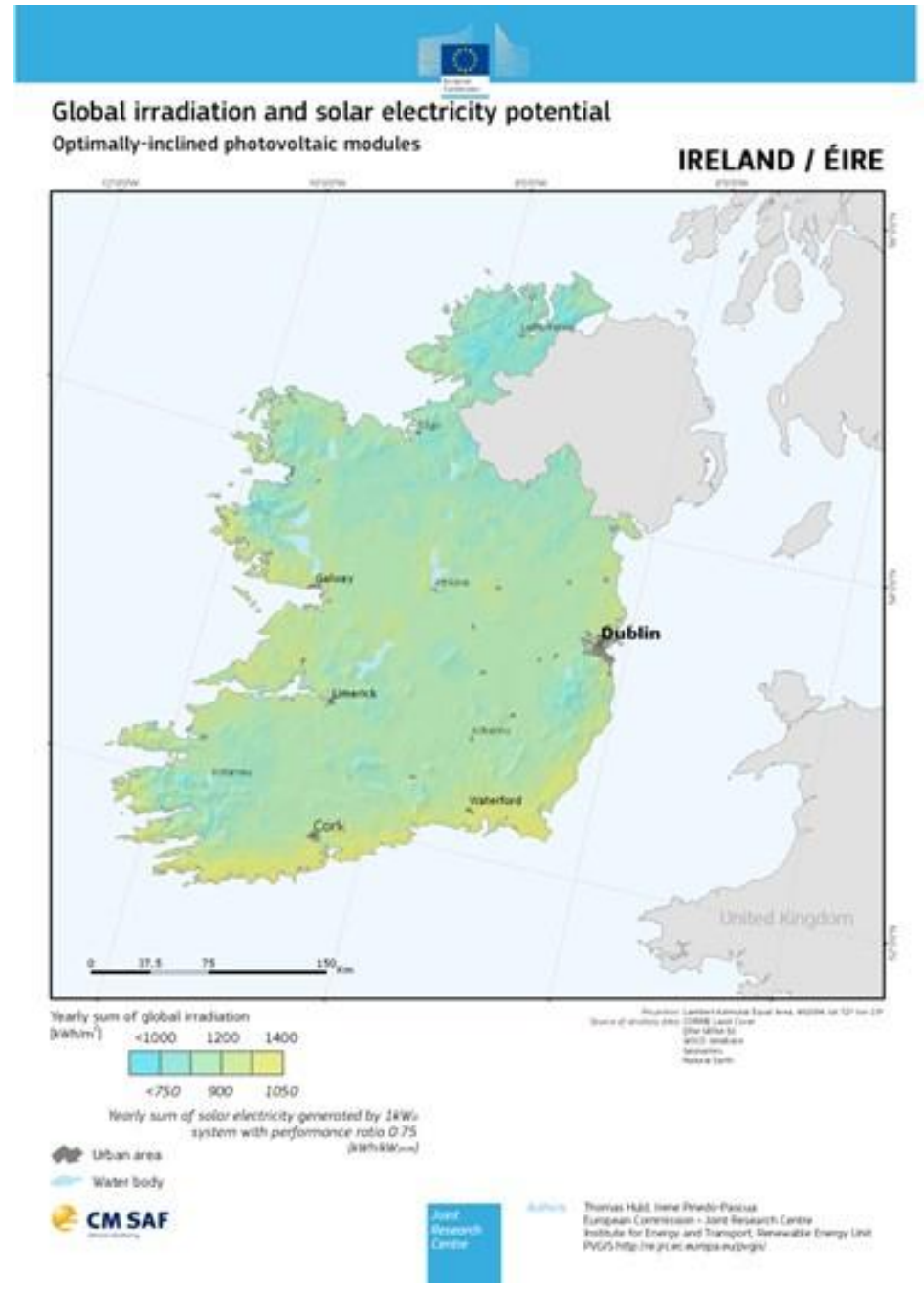

Figure 2. Global irradiation and solar electricity potential - Ireland for optimally inclined photovoltaic modules [13].

\subsubsection{Site Requirements and Planning Permission}

A number of site requirements must be taken into consideration when designing a solar PV array to ensure maximum power generation. Generally speaking, the more solar radiation and the more uniform the solar radiation (less solar diffusion) is on the solar panels, the greater the electricity generated. The levels of solar insolation received at the location are of great importance, as Figure 2 shows this varies across the country. Ideally the PV mounting position is due south, however some flexibility is possible, for example if it is within $\pm 20^{\circ}$ of due south this will permit collection of about $95 \%$ or more of the energy available at a variety of tilt angles [14].

The site should not be overshadowed by and obstacles which could prevent sunlight getting to the system and reducing its functionality. Shading of the solar arrays by buildings, trees, hills or even by other solar arrays should be minimised as this reduces the electrical output [14]. To prevent over-shadowing between the row of solar arrays, rows should be kept at a minimum of $4.8 \mathrm{~m}$ apart [15].

Installing a solar PV system in Ireland is usually subject to planning permission. However, the installation of these systems may be exempt from planning permission if installed under certain conditions [8]. These exemption conditions are stated in the Irish government report Planning and Development Regulations 2007 produced by the Department of Environment, Heritage and Local Government in January 2007 [16], and are stated for solar panels as; 
- The total aperture area of any such panel, taken together with any other such panel previously placed on or within the said curtilage, shall not exceed 12 square metres or $50 \%$ of the total roof area, whichever is the lesser.

- The distance between the plane of the wall or a pitched roof and the panel shall not exceed $15 \mathrm{~cm}$.

- The distance between the plane of a flat roof and the panel shall not exceed $50 \mathrm{~cm}$.

- The solar panel shall be a minimum of $50 \mathrm{~cm}$ from any edge of the wall or roof on which it is mounted.

- The height of a free-standing solar array shall not exceed $2 \mathrm{~m}$, at its highest point, above ground level.

- A free-standing solar array shall not be placed on or forward of the front wall of a house.

- The erection of any free standing solar array shall not reduce the area of private open space, reserved exclusively for the use of the occupants of the house, to the rear or to the side of the house to less than 25 square metres.

\subsubsection{Support Measures}

Feed-in-tariff schemes are the most popular supports for grid-connected PV systems in Europe, with the most successful systems operating in Germany and Italy [17]. A Renewable Energy Feed-In-Tariff (REFIT) is a policy mechanism aimed at encouraging investment in renewable energy systems by offering long-term contracts to renewable energy producers. REFIT is designed to provide price certainty to renewable electricity generators. It operates on a sliding scale, acting to ensure a guaranteed price for each unit of electricity exported to the grid by paying the difference between the wholesale price for electricity and the REFIT price. Solar PV systems are not currently supported under the REFIT programme in Ireland. The scheme supports wind, hydro and biomass energy [18]. Despite the current lack of support, the Government has indicated that support for the uptake of solar PV installations will be provided through the provision of a feed-in tariff rather than through grant aid in the future [6]. The intention to provide such a tariff is stated in the Programme for Government and SEAI has provided analysis of tariff options to the Department of Communications, Energy and Natural Resources [6].

Support for domestic grid integration of PV systems had been provided by a single electricity supplier, Electric Ireland, which offered a micro-generation feed-in tariff of $€ 0.09$ per kWh exported, which included solar PV, from 2009 to 2014 [19]. In April 2008, a new small and micro scale electricity generation programme was initiated by SEAI. The programme assessed technical, financial and regulatory issues surrounding the deployment of small and micro generation technologies in Ireland. This included a review of market arrangements required to encourage small and micro scale generation uptake, the definition of quality standards for products and installers, and a pilot trial and monitoring of 42 installations [6].

In a recent development, ESB (the state-owned electricity company) have partnered with Kingspan Group Plc. (a building materials company) to launch the 'Funded Solar' Scheme. Under this scheme, a business owner leases the roof of their building or buildings to Kingspan ESB for a period of 25 years. Kingspan ESB provides the funding to design, install and maintain the PV system on the roof. The business owner then enters into a power purchase agreement and agrees to purchase the electricity generated on the roof at a discounted rate [20]. A $300 \mathrm{~kW}$ solar photovoltaic system (the largest in the Republic of Ireland) has been installed at Kingspan Insulation in Castleblayney under this scheme.

In the absence of support, it is useful to note the current price of electricity for both domestic and commercial users as these rates may influence self-consumption of electricity from PV systems. Current average grid electricity prices for commercial and domestic users according to different usage bands are presented in Table 1. 
Table 1. Electricity Prices as summarized by Howley and Hammond [21].

\begin{tabular}{cccc}
\hline \multicolumn{2}{c}{ Business Electricity Prices (ex-VAT) } & \multicolumn{2}{c}{ Residential Electricity Prices (All Taxes Included) } \\
\hline Band & Price (c/kWh) & Band & Price (c/kWh) \\
\hline IA & 20.5 & DA & 48.1 \\
IB & 16.4 & DB & 30.7 \\
IC & 13.6 & DC & 24.5 \\
ID & 11.2 & DD & 21.1 \\
IE & 9.7 & DE & 18.1 \\
IF & 8.8 & - & - \\
\hline
\end{tabular}

\subsection{Environmental Impacts of Solar PV Systems}

A key driver for renewable energy systems implementation is the perceived carbon benefits which can be achieved when compared to conventional fossil energy systems. However, in determining the tangible environmental benefits of these systems, the entire life cycle must be taken into consideration. For example, biomass is often stated to be a carbon neutral fuel, however, research has shown that production of indigenous energy crops and harvesting and processing of wood biomass in Ireland is not carbon neutral when cultivation, harvesting, processing and transportation are taken into consideration [22,23].

Photovoltaic energy systems, directly generating electricity from solar energy, are free from fossil energy consumption and GHG emissions during operation. Therefore such systems would seem to be carbon neutral and cause no environmental burdens [24]. However, in determining the tangible environmental impacts of these systems, the entire life cycle must be taken into consideration, including PV system manufacture, operation, and disposal and/or recycling. When viewing PV systems in such a holistic manner, it is clear that energy production from such systems is directly linked to GHG emissions and thus these systems are not, in practice, emission free technologies [25].

Two indicators of sustainability, energy payback time (EPBT) and GHG emission rate, are commonly used to evaluate the energy and environmental performance of PV systems [26-28]. The energy payback time is defined as the period required for a renewable energy system to generate the same amount of energy (in terms of primary energy equivalent) that was used to produce the system itself [29].

GHG emissions, along with other environmental impacts, can be evaluated for PV systems using life cycle assessment (LCA), an internationally accepted tool for assessing the environmental sustainability of a system, product or service and provides the most comprehensive method currently available [30,31]. LCA is a method which can be used to analyse the environmental impacts of a system over its entire life-cycle, from raw materials acquisition through production, use and operation, and finally, end-of-life treatment, recycling and final disposal [32]. Environmental impacts are assessed based on a life cycle data inventory of relevant material and energy flows over the life-time of the system. In this sense, LCA is a "cradle-to-grave" approach as it begins with the gathering of raw materials from the earth to create the product and ends at the point when all materials are returned to the earth. In order to ensure harmonisation and standardisation of LCA studies, the methodology is governed by a set of international standards, ISO 14040 and ISO 14044; ISO 14040 describes the principles and framework for LCA, providing a basic explanation of the standard LCA process [32], ISO 14044 specifies minimum requirements and provides guidelines for an LCA [33]. Despite the presence of these LCA standards, studies examining similar PV systems have been found to show a large variance in results due to differences in methods and assumptions [34].

The environmental impacts of PV systems are dependent on the material and energy requirements in production, operation and maintenance, and disposal/recycling. The relation of the environmental impacts to the functional unit of the system, e.g., unit of electricity produced, is dependent on the energy generated by the system. The annual energy output is determined by a number of factors such as type of PV module, manufacture technologies, module conversion efficiency, installation location 
(roof top, façade or ground mounted) and pattern (integrated or mounted), array support structure, frame or frameless, application type (stand-alone or grid-connected) and performance ratio [24].

Several comprehensive reviews have been carried out on studies evaluating the sustainability of PV systems [24,35-37]. The type of PV technology utilised (and resource and energy inputs required), along with the installation location have been identified as important factors in the environmental performance of solar PV systems [25].

There is a wide range of available solar cell technologies, including; crystalline silicon technologies such as mono-crystalline (mono-Si), poly-crystalline (poly-Si), multi-crystalline (multi-Si) and ribbon multi-crystalline (ribbon-Si), and thin-film technologies such as amorphous silicon (a-Si), cadmium telluride (CdTe) and copper-indium-gallium-diselenide (CIGS). Each of these technologies has different material and processing requirements, leading to distinct emission profiles [25,38]. The solar conversion efficiencies of the different types of PV modules varies, which directly affects the energy return of the system [39].

Manufacturing of PV cells and associated components is an energy intensive process which requires direct fossil fuel use, generally for heating processes, and substantial electricity inputs [25], the use of which is significant over the life cycle [39]. The carbon intensity of the electric grid supplying the PV production chain has been shown to significantly affect life cycle GHG emissions [40], with emissions ranging from $1 \mathrm{~g} \mathrm{CO}_{2}$-eq per $\mathrm{kWh}$ electricity generated by $\mathrm{PV}$ when the manufacturing process is supplied by $100 \%$ renewable electricity, to $218 \mathrm{~g} \mathrm{CO}_{2}$-eq per $\mathrm{kWh}$ when the manufacturing process is supplied by coal electricity. This range of GHG emissions is still significantly lower than the carbon intensity of the Irish national grid at $457 \mathrm{~g} \mathrm{CO}_{2}$ per $\mathrm{kWh}$ in 2014 [1].

The location of the solar PV installation is important due to the differing levels of solar insolation across the globe, and on a local scale. The amount of electrical output generated by PV systems generally increases with an increase in solar radiation intensity consequently leading to lower E-PBTs [39]. Alsema and de Wild-Scholten [41] found that solar electricity generated in Germany produces approximately $70 \%$ higher GHG emissions than the same system installed in Spain.

\section{Materials and Methods}

\subsection{System Description}

The proposed site is an industrial building located at University College Dublin, $\left(52^{\circ} 59^{\prime} \mathrm{N}\right.$, $06^{\circ} 02^{\prime} \mathrm{W}$ ), Ireland. Irradiance data is taken from the nearest weather station at Dublin airport (which is circa $75 \mathrm{~km}$ north of the site) at $963 \mathrm{kWh} / \mathrm{m}^{2}$. The panels are to be roof-mounted. Average global inclined irradiation per square meter received by the modules is $1040 \mathrm{kWh}$ per year. The available roof area for mounting of PV panels is $784 \mathrm{~m}^{2}$. The PV modules hypothesised for use in this system, the Hanwha Q cells Q peak G3 275 Rev3 monocrystalline solar modules, have dimensions of $1670 \times 1000 \times 35 \mathrm{~mm}$, equating to a surface area of $1.67 \mathrm{~m}^{2}$. Each module has nominal power rating of $275 \mathrm{~W}_{\mathrm{p}}$. The panels have an efficiency of approximately $16.5 \%$. The system was modelled using PV*SOL software (Valentin Software GmbH, Berlin, Germany) (http:/ / www.valentin-software.com/ en/products/photovoltaics/57/pvsol-premium).

System details are outlined in Table 2. The installation is made up of $195 \mathrm{PV}$ panels composed of mono-silicon crystalline (c-Si) PV cells. The expected lifetime for the PV modules was assumed to be 30 years in line which has been proven to be attainable for c-Si modules [24], and is commonly used in LCA studies of such systems [42-44]. The lifetime of the inverter is assumed to be 15 years so it must be exchanged once during the lifetime of the installation [45]. In addition, it is assumed that damaged PV panels are replaced at a rate of $2 \%$ over the lifetime, and there is a production loss of $1 \%$ during handling. 
Table 2. Installation data.

\begin{tabular}{ccc}
\hline Installation Data & Unit & Quantity \\
\hline Global horizontal irradiation & $\mathrm{kWh} \cdot \mathrm{m}^{-2}$ & 963 \\
Roof area & $\mathrm{m}^{2}$ & 784 \\
Area per panel & $\mathrm{m}^{2}$ & 1.67 \\
Number of panels & & 195 \\
Total surface area & $\mathrm{m}^{2}$ & 325.7 \\
Nominal power & $\mathrm{Wp} \cdot \mathrm{panel}^{-1}$ & 275 \\
Total nominal power & $\mathrm{Wp}$ & 53,625 \\
Yearly output & $\mathrm{kWh}$ & 43,537 \\
& $\mathrm{kWh} \cdot \mathrm{kWp}^{-1}$ & 811.81 \\
\hline
\end{tabular}

\subsection{Environmental and Economic Assessment Methods}

The life cycle of photovoltaic energy systems begins with the extraction of raw materials for production (cradle), includes production of PV components and construction of the installations, and ends with the disposal (grave) of the PV components. Alternatively, PV components can be recovered and recycled and hence would then return to the cradle of the system. The environmental and economic assessment of the system was carried out using data from Table 2 and according to the assumptions outlined in Table 3.

Table 3. Assumptions.

\begin{tabular}{ccc}
\hline Installation Lifetime & Years & $\mathbf{3 0}$ \\
\hline Panel replacement rate & $\%$ & 2 \\
Loss during construction & $\%$ & 1 \\
\hline
\end{tabular}

The LCA for the proposed PV installation was modelled according to the ecoinvent dataset [45], which was modified to reflect specific operating conditions relating to Irish climatic conditions. Impacts related to operation and maintenance of the solar installation were considered negligible as documented by Turconi et al. [46]. The LCA was conducted in Simapro 8.0.1 [47].The energy payback time is defined as the period required for a renewable energy system to generate the same amount of energy (in terms of primary energy equivalent) that was used to produce the system itself [29]. The EPBT can be calculated using the following formula [29];

$$
\mathrm{EPBT}=\left(\mathrm{E}_{\text {mat }}+\mathrm{E}_{\text {manuf }}+\mathrm{E}_{\text {trans }}+\mathrm{E}_{\text {inst }}+\mathrm{E}_{\mathrm{EOL}}\right) /\left(\left(\mathrm{E}_{\mathrm{agen}} / \eta_{\mathrm{G}}\right)-\mathrm{E}_{\mathrm{O} \& \mathrm{M}}\right)
$$

where

$E_{\text {mat }}$ : Primary energy demand to produce materials comprising PV system,

$E_{\text {manuf: }}$ Primary energy demand to manufacture PV system,

$E_{\text {trans: }}$ Primary energy demand to transport materials used during the life cycle,

$E_{\text {inst: }}$ Primary energy demand to install the system,

$\mathrm{E}_{\mathrm{EOL}}$ : Primary energy demand for end-of-life management,

$\mathrm{E}_{\text {agen }}$ : Annual electricity generation,

$E_{O \& M}$ : Annual primary energy demand for operation and maintenance,

$\eta_{\mathrm{G}}$ : Grid efficiency, the average primary energy to electricity conversion efficiency at the demand side.

The energy required to produce the system is based on ecoinvent data (as referenced in Section 2.2), modified to reflect the specific requirements of the case study (transport distances etc.). Annual electricity generation was calculated for the specified system (details in Table 2) using PVSol software as mentioned in Section 2.1. 
The approach used in this study assumes the replacement of the national grid power mix with the PV system. This approach calculates the time needed to compensate for the total (renewable and non-renewable) primary energy required during the life cycle of the PV system (excluding the direct solar radiation input during the operation phase). The annual electricity generation $\left(E_{a g e n}\right)$ is converted into its equivalent primary energy, based on the efficiency of electricity conversion at the demand side, using the current average grid mix where the PV plant is installed [29]. A financial analysis was carried out to determine the effect of different potential renewable energy feed-in-tariffs on the overall economics of the proposed PV system. For this study, the payback time was considered to be the number of years before the system begins to generate profit. The equation below presents a simple method to determine the economic payback time of the solar PV system [48]:

$$
\text { Payback Time (years) }=\text { Cost of System }(€) / \text { Annual Savings or profits }(€)
$$

The system costs were calculated as $€ 123,026$ with each panel costing $€ 239$ [49], and installation costs of $€ 1,400$ per $\mathrm{kWp}$ according to Li et al. [8]. The cost of O\&M includes insurance and replacement of inverters and panels. It has been estimated as $1 \%$ of the investment cost [50,51]. In this study, it is assumed that the REFIT is in place for the full payback period.

The Irish Government has indicated that support for the uptake of solar PV installations will be provided through the provision of a feed-in tariff in the future [6], however there has been no announcement on possible REFIT rates. A number of possible REFIT rates were considered in this study based on existing REFIT rates for other renewable energy systems. Table 4 lists the existing REFIT rates considered.

Table 4. Existing Renewable Energy Feed-In-Tariff (REFIT) rates considered in this study (including balancing payment) [52].

\begin{tabular}{cccc}
\hline & Technology & Unit & Quantity \\
\hline 1 & Small wind $(<5 \mathrm{MW})$ & ${\text { cent } \mathrm{kWh}^{-1}}^{-1}$ & 8.2 \\
2 & Biomass Combustion & cent $\mathrm{kWh}^{-1}$ & 9.9 \\
3 & Large AD Non CHP $(>500 \mathrm{~kW})$ & cent kWh & 11.5 \\
4 & Large AD CHP $(>500 \mathrm{~kW})$ & cent kWh & \\
\hline
\end{tabular}

The levelised cost of electricity (LCoE) generated by the system was also calculated which represents the ratio between total lifetime costs of produced electricity, and the total estimated electric energy production in terms of the present value. The $\mathrm{LCoE}$ formula used can be given as:

$$
L C o E=\frac{\sum\left[\left(I_{t}+M_{t}\right)(1+r)^{-t}\right]}{\sum\left[E_{t}(1+r)^{-t}\right]}
$$

where $t$ is the year that costs and revenue take place, $I_{t}$ is the yearly investment cost, $M_{t}$ is the yearly O\&M cost, $r$ is the discount rate, and $E_{t}$ is the annual electricity generation [53]. Sensitivity analysis is carried out on $r$ by running the calculation of LCOE according to three $r$ values; $5 \%, 7.5 \%$ and $10 \%$.

\section{Results and Discussion}

\subsection{Life Cycle Assessment}

Life cycle GHG emissions from solar PV electricity generation are $69 \mathrm{~g} \mathrm{CO}_{2}$-eq per $\mathrm{kWh}$ generated. A breakdown of the contribution of each of the life cycle stages to total GHG emissions is shown in Table 5, including; inverter production and disposal, PV panel production and disposal, solar installation construction and disposal, transport of materials to and from solar installation, and electricity use in solar installation operation. The production of the PV panels is responsible for the 
majority of life cycle GHG emissions, accounting for 50\% of total emissions, echoing the findings of Hammond et al. [54]. Such emissions are largely due to energy use in production of the solar panels; energy use in PV panel production results in the emission of approximately $28 \mathrm{~g} \mathrm{CO}_{2}$-eq, almost $40 \%$ of total life cycle GHG emissions.

Table 5. Life cycle greenhouse gas emissions for the production of $1 \mathrm{kWh}$ of electricity the PV system.

\begin{tabular}{ccc}
\hline Impact Category & Unit & Quantity \\
\hline Inverter Production + Disposal & $\mathrm{g} \mathrm{CO}_{2}$-eq $\mathrm{kWh}^{-1}$ & 5.73 \\
PV Panel Production + Disposal & $\mathrm{g} \mathrm{CO}_{2}$-eq $\mathrm{kWh}^{-1}$ & 49.67 \\
Solar Installation Construction + Disposal & $\mathrm{g} \mathrm{CO}_{2}$-eq $\mathrm{kWh}^{-1}$ & 12.98 \\
Transport & $\mathrm{g} \mathrm{CO}_{2}$-eq kWh & 1.22 \\
Electricity & $\mathrm{g} \mathrm{CO}_{2}$-eq kWh & $4.87 \times 10^{-4}$ \\
Total & $\mathrm{g} \mathrm{CO}_{2}$-eq kWh & 69.61 \\
\hline
\end{tabular}

As mentioned previously, the type of PV technology utilised (and resource and energy inputs required), along with the installation location have been identified as important factors in the environmental performance of solar PV systems [25]. This study assumes the use of monocrystalline solar modules. Life cycle GHG emissions calculated in this study are higher than for the same technology installed in Southern Europe with a solar insolation level of $1700 \mathrm{kWh} / \mathrm{m}^{2}$, emissions in this case are $45 \mathrm{~g} \mathrm{CO}_{2}$-eq $\mathrm{kWh}^{-1}$ [26], highlighting the effect of high levels of solar radiation on overall GHG emissions. Furthermore, Reich [40] found that GHG emissions range from $1 \mathrm{~g} \mathrm{CO}_{2}$-eq $\mathrm{kWh}^{-1}$ when renewable energy is used in production, to $218 \mathrm{~g} \mathrm{CO}_{2}$-eq $\mathrm{kWh}^{-1}$ when coal is used in production.

Life cycle GHG emissions from solar electricity production in Ireland are significantly lower than GHG emissions from electricity production on the national grid of $457 \mathrm{~g} \mathrm{CO}_{2}$-eq per $\mathrm{kWh}$ [1]. However, GHG emissions from solar energy production are approximately twice as high as GHG emissions from biomass combined heat and power (CHP) systems in Ireland which produce $32.4 \mathrm{~kg} \mathrm{CO}$-eq per $\mathrm{kWh}$ [22]. It is important to note that GHG emissions from CHP systems depend on the type and source of biomass used. In addition, as CHP systems produce both heat and power, emissions are allocated not only to the electricity produced but also to the heat produced. There is a lack of data on GHG emissions from wind energy specific to Ireland, however average GHG emissions for wind have been estimated to be $34.11 \mathrm{~g} \mathrm{CO}_{2}$-eq per $\mathrm{kWh}$ according to Nugent and Sovacool [25]. Similarly to PV, manufacture of the wind turbine accounts for the majority of emissions (71\%), followed by construction (24\%), operation (approximately $24 \%$ ), and decommissioning, which offset $19.1 \%$ of wind's emissions. While solar electricity generation in Ireland causes higher GHG emissions than other renewable electricity systems, there remains scope for reducing total emissions as increasing penetration of renewables in electricity generation in general will result in reduced manufacturing emissions.

\subsection{Energy Pay Back Time}

The annual electricity output amounts to $43,537 \mathrm{kWh}(156,733 \mathrm{MJ})$ while the life cycle cumulative energy demand is $1,696,855 \mathrm{MJ}$. Using a grid conversion efficiency $\left(\eta_{\mathrm{g}}\right)$ of 0.483 for Ireland according to Howley et al. [55], the EPBT for the solar installation for the chosen site at University College Dublin is 5.23 years. In other words, it will take 5.23 years of operation of the solar plant to generate the same amount of energy (in terms of primary energy equivalent) that was used to produce the system itself. As such, if a lifetime of 30 is assumed, the system will be producing net energy for approximately 25 years. The EPBT is broadly similar to the EPBT of solar energy in the UK of 4.5 years [54]. However, the EPBT of a similar system in southern Europe has a shorter payback time of 2.7 years [26]. 


\subsection{Economic Analysis}

Annual income and the associated economic payback times at the various REFIT rates considered are presented in Figure 3. Results show that the time taken for the solar park to generate enough income to match the manufacturing and construction costs of the solar park vary between 19.3 and 34.4 years, depending on the REFIT rate.

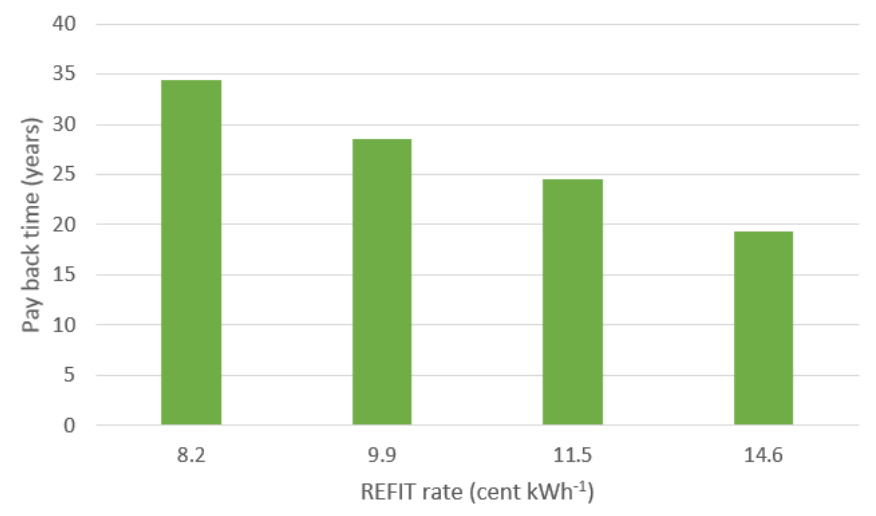

Figure 3. Economic payback time at different REFIT rates.

REFITs vary from country to country, some recent rates in European countries are; $€ 0.1381$ per kWh in France, $€ 0.1191$ per kWh (with self-consumption) in Germany, and 0.0818-0.1779 per kWh in the UK [14]. Differing REFIT rates and costs of production give rise to varying economic payback periods; $17-19$ years in France, $10-19$ years in Germany, and 13 years in the UK. To achieve a similar economic payback time in Irish conditions, the REFIT rate would need to be set at $€ 0.146$ per $\mathrm{kWh}$ in this analysis.

Levelised cost of electricity varies between 200 and 295 euro per MWh depending on the discount rate applied (see Table 6) calculated to be $€ 262$ per MWh. This LCoE is on the high end of a range of values calculated by Hernández-Moro and Martínez-Duart [56]. The results here are on the higher and of that range due to the lower level of solar resource available for the location, and as such the low capacity factor of 0.093 .

Table 6. Levelised cost of energy at different discount rates.

\begin{tabular}{cc}
\hline Discount Rate $(\%)$ & LCOE $\left(€ \mathbf{M W h}^{-\mathbf{1}}\right)$ \\
\hline 5 & 200 \\
7.5 & 246 \\
10 & 295 \\
\hline
\end{tabular}

The costs for the production of PV electricity in this study are higher than is usual in countries where the solar PV market is more developed, e.g., Germany, due to constraints with building integration and lack of experienced PV installers. The price of the PV system will be influenced strongly by the development of the Irish solar PV market and supply chain. As more PV is deployed, the Irish PV installer base will increase and 'learning by doing' effects will allow installers to install projects more efficiently and quickly under Irish conditions. These effects will apply in all parts of the solar PV supply chain, and are likely to be particularly strong in the rooftop market where installers must adapt to the particular characteristics of a country's building stock [57].

\section{Conclusions}

This study demonstrates the feasibility of a solar PV installation in University College Dublin from a technical, environmental and economic point of view. The system will produce net energy 
(net of the energy required to manufacture and install the system) from year 5.23 after installation. Solar electricity generated will yield significant GHG emissions savings when compared to the Irish national grid. Solar electricity has higher associated GHG emissions per kWh than wind and biomass CHP systems, however as energy use in production of the solar panels has a significant impact on overall emissions, future greening of national grids will result in reduced life cycle GHG emissions. The results of the study clearly demonstrate the importance of extending REFIT to include solar PV systems in order to achieve similar economic payback times as have been achieved in other European countries and to encourage the future uptake of PV in Ireland.

Acknowledgments: This study was funded under the Charles Parsons Energy Research Programme (Grant Number 6C/CP/E001) of Science Foundation Ireland (SFI).

Author Contributions: F.M. and K.McD. conceived and designed the experiments; F.M. performed the experiments; F.M. and K.McD. analyzed the data; F.M. wrote the paper.

Conflicts of Interest: The authors declare no conflict of interest.

\section{References}

1. Howley, M.; Holland, M.; Dineen, D.; Cotter, E. Energy in Ireland 1990-2014; Sustainable Energy Association Ireland: Sligo, Ireland, 2015.

2. Duffy, P.; Hanley, E.; Hyde, B.; O’Brien, P.; Ponzi, J.; Cotter, E.; Black, K. Ireland-National Inventory Report 2014-Greenhouse Gas Emissions 1990-2012 Reported to the United Nations Framework Convention on Climate Change; Environmental Protection Agency: Washington, DC, USA, 2014.

3. European Commission. Directive 2009/28/ec of the European Parliament and of the Council of 23 April 2009 on the Promotion of the Use of Energy from Renewable Sources and Amending and Subsequently Repealing Directives 2001/77/ec and 2003/30/ec; European Commission: Brussels, Belgium, 2009.

4. Department of Communications Energy and Natural Resources. National Renewable Energy Action Plan-Ireland; Department of Communications Energy and Natural Resources: Dublin, Ireland, 2010.

5. Murphy, F.; Devlin, G.; McDonnell, K. Benchmarking environmental impacts of peat use for electricity generation in ireland-A life cycle assessment. Sustainability 2015, 7, 6376-6393. [CrossRef]

6. Howley, M.; Holland, M.; O'Rourke, K. Renewable Energy in Ireland 2012; Sustainable Energy Association Ireland: Sligo, Ireland, 2014.

7. European Commission. Report from the Commission to the European Parliament, the Council, the European Economic and Social Committee and the Committee of the Regions-Renewable Energy Progress-com(2015) 293 Final; European Commission: Brussels, Belgium, 2015.

8. Li, Z.; Reynolds, A.; Boyle, F. Domestic integration of micro-renewable electricity generation in ireland-The current status and economic reality. Renew. Energy 2014, 64, 244-254. [CrossRef]

9. Met Éireann. Sunshine and Solar Radiation. Available online: http://www.met.ie/climate-ireland/sunshine. asp (accessed on 26 January 2017).

10. Huld, T.; Dunlop, E.D. Photovoltaic Geographical Information System (PVGIS). Available online: https:/ /ec.europa.eu/jrc/en/scientific-tool/photovoltaic-geographical-information-system-pvgisgeographical-assessment-solar-resource-and (accessed on 26 January 2017).

11. Acciona. Amareleja Photovoltaic Solar Plant-A World Benchmark in the Development of Renewable Energies. Available online: https://www.scribd.com/document/125604342/Amareleja-Photovoltaic-SolarPlant (accessed on 6 February 2017).

12. Juwi. Waldpolenze Solar Park. Available online: http://www.juwi.com/solar_energy/references/details/ waldpolenz_solar_park/-/-/5/1.html (accessed on 26 January 2017).

13. Huld, T.; Müller, R.; Gambardella, A. A new solar radiation database for estimating PV performance in europe and africa. Sol. Energy 2012, 86, 1803-1815. [CrossRef]

14. Sustainable Energy Association Ireland (SEAI). Best Practice Guide Photovoltaics (PV); Sustainable Energy Association Ireland: Sligo, Ireland, 2014.

15. Flood, E.; McDonnell, K.; Murphy, F.; Devlin, G. A feasibility analysis of photovoltaic solar power for small communities in ireland. Open Renew. Energy J. 2011, 4, 78-92. 
16. Government of Ireland. Planning and Development Regulations 2007-s.I. No. 83 of 2007; Government of Ireland: Dublin, Ireland, 2007.

17. Dusonchet, L.; Telaretti, E. Comparative economic analysis of support policies for solar PV in the most representative eu countries. Renew. Sustain. Energy Rev. 2015, 42, 986-998. [CrossRef]

18. Department of Communications Energy and Natural Resources. Refit. Available online: http://www.dcenr. gov.ie/Energy/Sustainable+and+Renewable+Energy+Division/REFIT.htm (accessed on 5 November 2014).

19. Electric Ireland. Electric Ireland Micro-Generation Pilot Scheme. Available online: https://www. electricireland.ie/ei/residential/price-plans/micro-generation-scheme.jsp (accessed on 23 January 2017).

20. Funded Solar. Available online: http://kingspanesb.com/about-funded-solar/ (accessed on 4 March 2016).

21. Howley, M.; Holland, M. Electricity \& Gas Prices in Ireland: 2nd Semester (July-December) 2015; Sustainable Energy Association Ireland: Sligo, Ireland, 2016.

22. Murphy, F.; Sosa, A.; McDonnell, K.; Devlin, G. Life cycle assessment of biomass-to-energy systems in ireland modelled with biomass supply chain optimisation based on greenhouse gas emission reduction. Energy 2016, 109, 1040-1055. [CrossRef]

23. Murphy, F.; Devlin, G.; McDonnell, K. Greenhouse gas and energy based life cycle analysis of products from the irish wood processing industry. J. Clean. Prod. 2015, 92, 134-141. [CrossRef]

24. Peng, J.; Lu, L.; Yang, H. Review on life cycle assessment of energy payback and greenhouse gas emission of solar photovoltaic systems. Renew. Sustain. Energy Rev. 2013, 19, 255-274. [CrossRef]

25. Nugent, D.; Sovacool, B.K. Assessing the lifecycle greenhouse gas emissions from solar PV and wind energy: A critical meta-survey. Energy Policy 2014, 65, 229-244. [CrossRef]

26. Fthenakis, V.; Alsema, E. Photovoltaics energy payback times, greenhouse gas emissions and external costs: 2004-early 2005 status. Prog. Photovolt. Res. Appl. 2006, 14, 275-280. [CrossRef]

27. Mason, J.E.; Fthenakis, V.M.; Hansen, T.; Kim, H.C. Energy payback and life-cycle $\mathrm{CO}_{2}$ emissions of the bos in an optimized 3.5 MW PV installation. Prog. Photovolt. Res. Appl. 2006, 14, 179-190. [CrossRef]

28. Laleman, R.; Albrecht, J.; Dewulf, J. Life cycle analysis to estimate the environmental impact of residential photovoltaic systems in regions with a low solar irradiation. Renew. Sustain. Energy Rev. 2011, 15, 267-281. [CrossRef]

29. Fthenakis, V.; Frischknecht, R.; Raugei, M.; Kim, H.C.; Alsema, E.; Held, M.; de Wild-Sholten, M. Methodology Guidelines on Life Cycle Assessment of Photovoltaic Electricity, 2nd ed.; IEA PVPS Task 12; International Energy Agency Photovoltaic Power Systems Programme; International Energy Agency: Paris, France, 2011.

30. Evans, A.; Strezov, V.; Evans, T.J. Assessment of sustainability indicators for renewable energy technologies. Renew. Sustain. Energy Rev. 2009, 13, 1082-1088. [CrossRef]

31. Kloepffer, W. Life cycle sustainability assessment of products. Int. J. Life Cycle Assess. 2008, 13, 89-95. [CrossRef]

32. International Organization for Standardization (ISO). ISO 14040:2006-Environmental Management-Life Cycle Assessment-Principles and Framework; International Organization for Standardization: Geneva, Switzerland, 2006.

33. International Organization for Standardization (ISO). En ISO 14044:2006: Environmental Management-Life Cycle Assessment-Requirements and Guidelines; International Organization for Standardization: Geneva, Switzerland, 2006.

34. Hsu, D.D.; O’Donoughue, P.; Fthenakis, V.; Heath, G.A.; Kim, H.C.; Sawyer, P.; Choi, J.-K.; Turney, D.E. Life cycle greenhouse gas emissions of crystalline silicon photovoltaic electricity generation. J. Ind. Ecol. 2012, 16, S122-S135. [CrossRef]

35. Gerbinet, S.; Belboom, S.; Léonard, A. Life cycle analysis (LCA) of photovoltaic panels: A review. Renew. Sustain. Energy Rev. 2014, 38, 747-753. [CrossRef]

36. Lamnatou, C.; Chemisana, D.; Mateus, R.; Almeida, M.G.; Silva, S.M. Review and perspectives on life cycle analysis of solar technologies with emphasis on building-integrated solar thermal systems. Renew. Energy 2015, 75, 833-846. [CrossRef]

37. Sherwani, A.F.; Usmani, J.A.; Varun. Life cycle assessment of solar PV based electricity generation systems: A review. Renew. Sustain. Energy Rev. 2010, 14, 540-544. [CrossRef]

38. Kim, H.C.; Fthenakis, V.; Choi, J.-K.; Turney, D.E. Life cycle greenhouse gas emissions of thin-film photovoltaic electricity generation. J. Ind. Ecol. 2012, 16, S110-S121. [CrossRef] 
39. Pacca, S.; Sivaraman, D.; Keoleian, G.A. Parameters affecting the life cycle performance of PV technologies and systems. Energy Policy 2007, 35, 3316-3326. [CrossRef]

40. Reich, N.H.; Alsema, E.A.; van Sark, W.G.J.H.M.; Turkenburg, W.C.; Sinke, W.C. Greenhouse gas emissions associated with photovoltaic electricity from crystalline silicon modules under various energy supply options. Prog. Photovolt. Res. Appl. 2011, 19, 603-613. [CrossRef]

41. Alsema, E.A.; de wild-Scholten, M.J. Environmental life cycle assessment of advanced silicon solar cell technologies. In Proceedings of the 19th European Photovoltaic Solar Energy Conference, Paris, France, 7-11 June 2004.

42. Fthenakis, V.; Kim, H.C.; Frischknecht, R.; Raugei, M.; Sinha, P.; Stucki, M. Life Cycle Inventories and Life Cycle Assessment of Photovoltaic Systems; Pvps task 12, report t12-02:2011; International Energy Agency (IEA): Paris, France, 2011.

43. Alsema, E.A.; de Wild-Sholten, M.J. Environmental impacts of crystalline silicon photovoltaic module production. In Proceedings of the 13th CIRP International Conference on Life Cycle Engineering, Leuven, Belgium, 31 May-2 June 2006.

44. Raugei, M.; Frankl, P. Life cycle impacts and costs of photovoltaic systems: Current state of the art and future outlooks. Energy 2009, 34, 392-399. [CrossRef]

45. Jungbluth, N.; Tuchschmid, M. Photovoltaics. In Sachbilanzen von Energiesystemen: Grundlagen für den Ökologischen Vergleich von Energiesystemen und den Einbezug von Energiesystemen in Ökobilanzen für die Schweiz; Dones, R., Ed.; Ecoinvent Report no.6-xii, Swiss Centre for Life Cycle Inventories: Dübendorf, Switzerland, 2007.

46. Turconi, R.; Boldrin, A.; Astrup, T. Life cycle assessment (lca) of electricity generation technologies: Overview, comparability and limitations. Renew. Sustain. Energy Rev. 2013, 28, 555-565. [CrossRef]

47. PRé Consultants. Simapro 8.0.1, PRé Consultants: Amersfoort, The Netherlands, 2013.

48. Wies, R.W.; Johnson, R.A.; Agrawal, A.N.; Chubb, T.J. Simulink model for economic analysis and environmental impacts of a PV with diesel-battery system for remote villages. Power Syst. IEEE Trans. 2005, 20, 692-700. [CrossRef]

49. Photovoltaik4all. Q-cells q.Peak-g3 275w Mono Mit Schwarzen Rahmen. Available online: http:/ /www.photovoltaik4all.de/pv4all-netz/solarmodule/q-cells/98/q-cells-q.peak-g3-275w-monomit-schwarzen-rahmen (accessed on 5 March 2016).

50. International Renewable Energy Agency (IRENA); Energy Technology System Analysis Programme IEA-Etsap. Technology Policy Brief e11; The International Renewable Energy Agency (IRENA): Abu Dhabi, United Arab Emirates, 2013.

51. International Energy Agency. Energy Technology Perspectives. Technology Roadmap: Solar Photovoltaic Energy, 2014th ed.; International Energy Agency: Paris, France, 2014.

52. Department of Communications Energy and Natural Resources. Renewable Energy Feed in Tariff-Reference Prices; Department of Communications Energy and Natural Resources: Dublin, Ireland, 2015.

53. International Energy Agency. Projected Costs of Generating Electricity-2005 Update; Organisation for Economic Co-Operation and Development: Paris, Frence, 2005.

54. Hammond, G.P.; Harajli, H.A.; Jones, C.I.; Winnett, A.B. Whole systems appraisal of a uk building integrated photovoltaic (bipv) system: Energy, environmental, and economic evaluations. Energy Policy 2012, 40, 219-230. [CrossRef]

55. Howley, M.; Holland, M.; Dineen, D. Energy in ireland 1990-2013; Sustainable Energy Association Ireland: Sligo, Ireland, 2014.

56. Hernández-Moro, J.; Martínez-Duart, J.M. Analytical model for solar PV and csp electricity costs: Present lcoe values and their future evolution. Renew. Sustain. Energy Rev. 2013, 20, 119-132. [CrossRef]

57. KPMG. A Brighter Future-The Potential Benefits of Solar PV in Ireland; Irish Solar Energy Association: Dublin, Ireland, 2015.

(C) 2017 by the authors; licensee MDPI, Basel, Switzerland. This article is an open access article distributed under the terms and conditions of the Creative Commons Attribution (CC BY) license (http:/ / creativecommons.org/licenses/by/4.0/). 